BULLETIN OF PNRPU. GEOLOGY. OIL \& GAS ENGINEERING \& MINING ВЕСТНИК ПНИПУ. ГЕОЛОГИЯ. НЕФТЕГАЗОВОЕ И ГОРНОЕ ДЕЛО

ISSN 2224-9923

Volume/ TOM 15 №19 2016

http://vestnik.pstu.ru/geo/

УДК 551.14:550.83: 551.24:550.83

Article / Статья

(C) PNRPU / ПНИПУ, 2016

\title{
DISCOVERY OF HYDROCARBON ACCUMULATIONS FORMED UNDER NATURAL CONDITIONS OF OCCURRENCE BASED ON FIELD DATA
}

\section{V.Sh. Gurbanov, O.B. Babazade ${ }^{1}$, L.A. Sultanov, I.I. Guliev ${ }^{2}$}

Azerbaijan State Oil and Industry University (20 Azadlyg av., Baku, AZ1010, Republic of Azerbaijan)

${ }^{1}$ Institute of Geology and Geophysics of Azerbaijan National Academy of Science (119 G. Javid av., Baku, AZ1143, Republic of Azerbaijan)

${ }^{2}$ Oil and Gas Research and Design Institute of the State Oil Company of the Azerbaijan Republic

(88 G. Zardabi av., Building A, Baku, AZ1012, Republic of Azerbaijan)

\section{ОПРЕДЕЛЕНИЕ НАЛИЧИЯ УГЛЕВОДОРОДНЫХ ЗАЛЕЖЕЙ В ЕСТЕСТВЕННЫХ УСЛОВИЯХ ЗАЛЕГАНИЯ НА ОСНОВЕ ПРАКТИЧЕСКИХ ДАННЫХ}

\section{В.Ш. Гурбанов, О.Б. Бабазаде ${ }^{1}$, Л.А. Султанов, И.И. Гулиев ${ }^{2}$}

Азербайджанский государственный университет нефти и промышленности (AZ1010, Азербаджанская Республика, г. Баку, пр. Азадлыг, 20)

${ }_{1}^{1}$ Институт геологии и геофизики Национальной академии наук Азербайджана

(AZ1143, Азербаджанская Республика, г. Баку, пр. Г. Джавида, 119)

${ }^{2}$ НИПИ «Нефтегаз» Государственной нефтяной компании Азербайджанской Республики

(AZ1012, Азербаджанская Республика, г. Баку, пр. Г. Зардаби, 88А)

Получена / Received: 22.01.2016. Принята / Accepted: 20.04.2016. Опубликована / Published: 30.06.2016

Key words:

geological structure, medium stratification, sedimentation conditions, reservoir, seismic exploration, resistivity prospecting, gravimetric prospecting, geological criteria, geophysical features, hydrocarbon accumulations, seismic waves, resistivity, velocity, density, amplitude, frequency.
Ключевые слова:

геологическое строение, слоистость среды, условия седиментасии, среды, условия седимен-

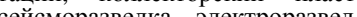
сайоразведка, электроразведск, гравиразведк, телонские кригей, геофизические признаки, углеводородные залежи, сейсмические волны, удельное сопротивление, скорость, плотность, амплитуда, частота.
In order to detect, determine thickness and localize hydrocarbon accumulations there are qualitative and quantitative methods of interpretation still in use. Such methods are not divided into geological criteria and geophysical features which cause

The study is based on the theory of appearance processes and composition formation as well as on conditions of occurrence of oil and gas. Deep structure such as gas-steam-conductive faults and oil-gas-steam-distributing faults of low order were studied. All the features of its determination under natural conditions of occurrence were integrated. Based on listed above and on results of several years of experimental and operating works, carried by other scientists in order to discover hydrocarbon accumulation in geological structure the authors determined and grouped geological criteria and geophysical features.

Furthermore, during determination of geological criteria and geophysical features following petrophysical parameters of reservoir properties are determined: porosity, saturation, effective porosity, reservoirs density and speed of seismic wave propagation in the rock, rock and fluid resistivity.

It should be noted, that during interpretation of seismic data to discover hydrocarbon migration tame and deep cross-sections as well as simultaneous cross-sections, frequencies and phases were used. The charts of amplitudes, frequencies, phases and its dispersion, decrement and attenuation coefficients that are equivalents to absorption coefficients and differences of and tic vibrations of reflected waves were used.

Finally, having these parameters determined geological criteria and geophysical features of discovery of hydrocarbon accumulations under natural conditions of occurrence were grouped.

Для обнаружения наличия, определения мощности и локализации углеводородных залежей до сих пор на практике используются качественные и количественные способы интерпретации без разделения их на геологические критерии и геофизические признаки, что, безусловно, приводит к определенным ошибкам.

Вии и геофизические признаки, что, безусловно, приводит к определенным ошибкам. В связи с этим, основываясь на теории процессов образования, формирования состава и условиях залегания нефти и газа; детально изучая глубинное геологическое строение, в частности устанавливая на временных разрезах наличие глубинных разломов, являющихся газопароподводящими, и разломов низкого порядка, являющихся нефтегазоларораспредяющ а также на основании результатов многолетних экепериментальных и производственных работ, проводимых другими исследователями, авторы установили и сгруппировали геологические критерии и геофизические признаки по определению наличия углеводородных залежей в геологическом строении.

Кроме того, при установлении геологических критериев и геофизических признаков с высокой точностью определяются петрофизические параметры коллекторских пластов, такие как пористость, насыщенность и, соответственно, эффективная пористость, являющаяся их произведением, пластовые плотности и скорости распространения сейсмических волн и удельное электрическое сопротивление пласта, плотность и скорость распространения сейсмических волн и удельное электрическое сопротивление скелета горных пород, слагающих коллекторских пластов и заполняющих их флюидов. Следует отметить, что кроме вышеперечисленных петрофизических параметров при интерпретации сейсмических данных для обнаружения углеводородных залежей были использованы миграционные временные и глубинные разрезы и разрезы мгновенных амплитуд, частот и фаз, а также использованы графики амплитуд, частот, фаз и их дисперсии, декремент и коэффициенты затухания, являющиеся эквивалентом коэффициентов поглощения и расхождения упругих колебаний отраженных волн.

В итоге после определения этих параметров были сгруппированы геологические критерии и геофизические признаки обнаружения углеводородных залежей в естественных условиях залегания.

\footnotetext{
Vagif Sh. Gurbanov (Author ID in Scopus: 26028826000) - Doctor of Geological and Mineralogical Sciences, Professor at the Department of Oil and Gas Fields Survey and Exploration (mob. tel.: +994 5036552 94, e-mail: vagifqurbanov@mail.ru).

Oktai B. Babazade (Author ID in Scopus: 55352800300) - Doctor of Physics and Mathematics, Professor, Head of Laboratory (mob. tel.: +994 506282703 , e-mail: oktay_babazade@yahoo.com).

Latif A. Sultanov - Researcher at the Department of Oil and Gas Fields Survey and Exploration (mob. tel.: +994 50 327 97 01, e-mail: latif.sultan@mail.ru). Ilgam I. Guliev - Engineer (mob. tel.: +994 5030660 26, e-mail: ilham_br@mail.ru). The contact person for correspondence.

Гурбанов Вагиф Шыхы оглы - доктор геолого-минералогических наук, профессор кафедры поиска и разведки нефтяных и газовых месторождений (моб. тел.: +994 5036552 94, е-mail: vagifqurbanov@mail.ru).
Бабазаде Октай Баба оглы - доктор физико-математических $\quad$ наук, профессор, заведующий лабораторией $\quad$ (моб. тел.: +994 $5062827 \quad 03$,
e-mail: oktay babazade@yahoo.com). e-mail: oktay_babazade@yahoo.com). Султанов Латиф Агамирза оглы - научный сотрудник кафедры поиска и разведки нефтяных и газовых месторождений (моб. тел.: +994 503279701 , e-mail: latif.sultan@mail.ru).

Гулиев Ильгам Идрис оглы - инженер (моб. тел.: +994 5030660 26, e-mail: ilham_br@mail.ru). Контактное лицо для переписки.
} 


\section{Introduction}

Analysis of theoretical basis to predict fluidsaturated media and fluids by geophysical exploration methods and their synthesis are given in this article in order to use in production.

Summary of results of several years of experimental and production works performed by scientists previously during forecast of hydrocarbon accumulation and analysis of physics and mathematics of geophysical methods (seismic exploration, resistivety prospecting and gravimetric prospecting), petrophysical properties of reservoirs and physical features of fluids were the basis to group following exploration criteria and features of hydrocarbon fields discovery [1-17]:

1. Geological criteria.

2. Geophysical features.

\section{Geological criteria \\ to discover hydrocarbon accumulation in geological structure}

Summary of formation processes and conditions of hydrocarbon occurrence allows to distinguish following geological criteria to discover hydrocarbon in geological structure [1-3]:

1. Deep gas-steam-conductive faults (migration channels).

2. Dispersed organic matter in geological cross-sections.

3. Migration faults that are oil-gas-steamdistributing for first and second hydrocarbons.

4. Reservoirs that have pores and cracks of effective porosity more than $2 \%$.

5. Anticlines, domes, bars, monoclines, stratigraphic unconformities, riffs, lenses, paleo channels etc.

6. Seals that are not permeable and represent screen which block oil, gas, condensate, water and its vapor to flow upside.

7. Lateral limit that does not allow oil, gas, condensate and water to move laterally.

8. Unconformity of morphology of seals with underlying sediments detected on temporary and seismic deep cross-sections.
9. Deep-buried part of crystal foundation and superimposed structure.

Thus, based on mentioned geologic criteria it is possible to determine fluids in the geological cross-section of studied areas during exploration of oil, gas and condensate fields.

\section{Geophysical features of discovery of hydrocarbon accumulation in geological structure}

In order to determine geophysical features of hydrocarbon presence under natural conditions an analysis of theory that forecast fluid-saturated media and fluids by geophysical methods of exploration is done [4-8].

Based on the analysis of the theory and field data it can be concluded that seismic shear waves do not propagate in fluids, but longitudinal do. On the other hand, it is also known that the longitudinal seismic waves propagating in fluids lose some of its energy due to divergence and absorption. As a result, their dynamic parameters change. For example, amplitude of elastic vibrations are reduced and attenuation coefficients, which are equivalent to the absorption coefficients and the differences increase.

Moreover, it is also known that velocity of seismic wave propagation in fluids and fluidcontaining reservoir is much less than velocity of rock matrix. Therefore, on seismograms and time sections of reflected waves in the hodograph longitudinal reflected, refracted and transmitted waves there is a time delay of their travel. Simultaneously, there is an increase of observable periods and decrease of frequency of elastic vibrations on recorded seismic signals.

Considering factors of wave field physical phenomena during several years a lot of investigators while forecast of hydrocarbon deposits have started to apply full-wave seismic survey in order to use both longitudinal, transverse and converted waves, since they can help to determine exact location of fluids on its way.

Discovery of hydrocarbon accumulations in the overlying and underlying medium using full-wave seismic survey carried out as follows: 
- a desired object is located in overburden in the area of incident waves, wave types $P P P, P P S$, $P S P, P S S, P P$ and $P S$ are registered, there are no wave types such as SSS, SSP, SPS, SPP, SP and $S S$;

- a desired object is located in overburden, in the reflection or refraction area wave types $P P P$, $S P P, P S P, S S P, P P$ and $S P$ are recorded, there are no wave types $S S S, S P S, P P S, P S S$, $S S$ and $P S$;

- a desired object is in underlying medium, in an area below refractor, wave types $P P P, S P P$, $P P S, S P S$ are recorded and there are no wave types SSS, SSP, PSP, PSS.

Besides, it was found that changes in values of dynamic and kinematic parameters of longitudinal reflected, refracted and transmitted waves depend on power and phase of hydrocarbon compounds and formation water, reservoir saturation, porosity as well as pressure and temperature.

During the processing and interpretation of seismic data obtained by methods of reflected, refracted and transmitted waves, the authors found that all kinds of longitudinal waves passing through fluids (particularly through gas reservoir) produce in the corner of its trap dynamic mature longitudinal diffracted waves.

Also, according to actual seismic data authors found that from the oil-water and water-gas contact reflection that is so-called "flat spot" is registered. Reflection from these contacts is always recorded with a horizontal axis phase synchronism that is characterized by an angular unconformity with axis of phase synchronism of waves reflected from top and bottom of a formation. Wherein reflection coefficient of these contacts have the same order of magnitude as from the other media boundaries.

This boundary has two characteristics: 1) limited length of media boundary in case of small thickness and high angle of boundary of media saturated by fluid can be less than Frenel zone that leads to decrease in reflection intensity from the boundary; 2) non-mirror and gritty nature of the border causes an amplitude dependence of the reflection from a frequency range of research.
Secondary transformation may occur in the contact area, i.e. reduced porosity and increased density of the water-saturated rocks.

In the analysis of electrical exploration data obtained earlier [16, 17], it was found that the value of resistivity of oil, gas and condensate is very high and ranges from $10^{6}$ to $10^{14} \mathrm{Ohm} \cdot \mathrm{m}$. In this regard, resistivity of formations saturated by water is significantly reduced from 0.01 to $100 \mathrm{Ohm} \cdot \mathrm{m}$. On the other hand it was found that the higher reservoir temperature the lower resistivity and the higher the geostatic pressure (gravity effect) the higher resistivity of formation saturated by fluid.

Furthermore, field data show that relatively small group of rocks (metal nuggets minerals, sulfides, certain oxides, carbons and carbonized graphite) has electron conductivity and the higher the concentration of such minerals in the rocks the lower resistivity.

Main rock-forming minerals such as silicates, most oxides (quartz etc.), carbonates (calcium etc.), nitrates, phosphates and the like have very high resistivity. Most igneous rocks are characterized by high resistivity and change in the value of resistivity of these rocks depends on many physical and geological factors, in particular on their structure, texture, mineral composition etc.

Texture and structure of rocks mainly affect their electrical anisotropy, due to the existence of which resistivity along the lamination $\left(\rho_{t}\right)$ in most cases is smaller than across $\left(\rho_{a}\right)$, i.e. $\rho_{t}<\rho_{a}$. In case of reverse phenomenon anisotropy paradox is observed. Fluids in geological structure (under natural conditions of occurrence) are discovered with detection of negative local anomalies in gravitational fields.

Thus, in the analysis of seismic, gravimetric and electrical exploration data obtained previously by researchers during prediction of hydrocarbon, authors established following geophysical features of detection of hydrocarbon accumulations in the geological structure:

1. Seismic shear waves do not propagate in fluids, therefore are not presented on seismograms in presence of fluids in geological structure. 
2. When longitudinal, reflected and refracted waves pass from borders below object of interest there is a decreased values of effective and reservoir velocities and frequencies of elastic vibrations, increase of attenuation coefficients, travel time and visible periods of seismic waves.

3. Having considered factors above and taking into account reference data authors grouped following seismic characteristics. Kinematic, dynamic, morphological, structural and formational group of features [4-8]:

\section{A. Kinematic features:}

- increase of time interval between reflections of overlying and underlying layers of hydrocarbon accumulations;

- decrease of time interval between reflections of covering layers of hydrocarbon accumulations;

- increase of a number of signal phases of reflected waves coming from underlying layer and passing through hydrocarbon accumulations;

- increase of travel time of reflected waves from underlying layers and passing through hydrocarbon accumulations;

- increase of formation speed between the covering layers of hydrocarbon accumulations;

- decrease of formation (interval) speed in the presence of hydrocarbon accumulations;

- increase of formation speed between underlying layers in presence of hydrocarbon accumulations.

B. Dinamic features:

- decrease of amplitudes of elastic vibrations of reflected waves coming from underlying layers and passing through hydrocarbon accumulations;

- increase of amplitudes of elastic vibrations of reflected waves (bright spot), coming from covering layers (surfaces) of hydrocarbon accumulations;

- decrease of amplitudes of elastic vibrations of reflected waves (dark or dim spot), coming from the underlying layers (from the base and below) of hydrocarbon accumulations;

- increase of period and decrease of frequency (spectrum frequency) of elastic vibrations of reflected waves coming from the underlying layers (from the base and below) and passing through hydrocarbon accumulations;
- decrease of period (increase of frequency) of elastic vibrations of reflected waves coming from the covering layers (from the roof and above) of hydrocarbon accumulations;

- increase of attenuation coefficient of elastic vibrations of reflected waves coming from underlying layers (from the base and below) and passing through the hydrocarbon accumulations;

- decrease of attenuation coefficient of elastic vibrations of reflected waves coming from the covering layers (from roof and above) of hydrocarbon accumulations;

- increase in relative dispersion of instant $\sigma_{f} / f$ frequency in an area with hydrocarbon accumulations;

- increase in relative dispersion of instant phases of $\sigma_{\varphi} / \varphi$ in an area with hydrocarbon accumulations;

- a local change of polarity of reflected waves at the corners of contacts between hydrocarbons and reservoir rocks;

- an increase in intensity energy of reflected and diffracted waves generated at the corner points of contacts between hydrocarbons and reservoir rocks;

- increase of energy of reflected waves coming from layers covering (roof and above) in an area with hydrocarbon accumulations;

- decrease in energy of reflected waves coming from underlying layers (from the base and below) and passing through hydrocarbon accumulations;

- change in relative dispersion of lateral reflection coefficient $K_{\text {ref; }}$;

- increase of average reflection coefficient module $\left|K_{\text {ref }}\right|$ layers in the area covering (from the roof and above) of hydrocarbon accumulations;

- decrease of average reflection coefficient module $\left|K_{\text {ref }}\right|$ in underlying layers (base and lower) of hydrocarbon accumulations.

C. Morphologic (discovery of hydrocarbon traps on migration time sections for configurations) features:

- anticline (tectonic) traps have isometric (domes), slightly elongated (brachyanticline) and linearly-extended (anticline) forms of folds. 
On migration time cross-section domes are expressed in almost symmetrically convex shape of axis of phase synchronism, and shape of brachyanticline is convex on one side only or slightly stretched in both directions. Anticline folds have a convex shape and are strongly stretched in both directions.

In accordance with structural shapes anticline traps may be:

a) Through: when an axis of phase synchronism of seismic horizons can be traced from the crystalline basement to the surface in inherited form. Often these phenomena are expressed even in the present relief. Within these inherited arches anticline traps are coincide and shifting aside sometimes;

b) Buried: associated with wedges of the crystalline basement, where seismic horizons have certain amplitude that attenuate up to the srosssection until horizontality; anticline trap are blocked by horizontal horizontals from the top;

c) Hinged: located in a limited range and do not have roots in the crystalline basement. Anticline trap accompanied by horizontal phase synchronism axis of reflected waves coming from covering and underlying sediments.

- Nonanticlinal (stratigraphic, lithological, complex (lithologic and stratigraphic) and reef) traps in terms of features can be categorized as follows:

a) reservoirs are stratigraphic traps, connected to pinching out layer. Pinching out line and cut surface are lateral screen. In this case, it is necessary to determine where the pinching out layer is: on monoclines or on anticline wings. In all the options pinching out is accompanied by merge of axial phase synchronism of reflected waves coming from the top and bottom of pinching out layers, and a straight line of phase synchronism of reflected waves coming from the cut surface;

b) reservoirs are lithological traps associated with facies replacement of layers. These traps may be located on anticlines and monoclines. Lenses and layer inclusions of paleo channel, paleo delta and other forms of sedimentation, which are presented by clastic (sandy) sediments are related to lithologi- cal traps. Lens inclusions on migration time section are allocated by presence of parallel axis phase synchronism horizons overlying and underlying sediments. Pinching out both at the beginning and at the end of the phase synchronism are lateral screens.

Traps of reservoir inclusions represent chaotic records of symmetrical signals that are detected by presence of homogeneous, heterogeneous, nonlayered and strongly crumpled media with no reflection. The zone is limited to the top and bottom by parallel axis phase synchronism of covering and underlying layers.

Lateral screens of reservoir inclusion on migration time section are characterized by presence of homogeneous and heterogeneous rocks within the formation, where layered axis phase synchronism of reflected waves are traced.

In the traps of paleo channels and deltas on migration time section some areas with lack of reflection were found coming from the media of homogeneous stratified rocks;

c) complex traps that have complicated and difficult to determined shape of folds (monocline fall of layers with sand bodies, which have screens presented by line of cut surface). They are found during determination of true speeds in reservoirs, rock matrix and fluids.

d) reef traps associated with organogenic constructions - barrier, shelf, coastal (boundary) etc. For a number of specific features, especially in the facies complex, reefs appear in a seismic field, i.e., according to the shape of axis phase synchronism reef structures are determined;

D. Structurally formational (age determination, establishment of sedimentation conditions and study of form of folds) features:

a) seismic facies change (change of crossbedding to chaotic, delta or vice versa) within the parallel layered covering and underlying sediments. On migration time section of cross-bedding axis of phase synchronism are surrounded by chaotic records in a trap area;

b) lateral change of layering types surrounded by traps, i.e. cross-bedding sediments are fixed to a trap, change to parallel layered sediments. On 
migration time section cross-beddings axis of phase synchronism around a trap change to parallel layered axis of phase synchronism.

c) lateral change of frequency of stratification around the trap. From the one hand, trap crowding (compactions) upside down is observed. From the other hand there is an expansion of trap layers (decompactions). Axis of phase synchronism of reflected waves behave the same way.

4. Longitudinal diffracted waves are formed at the end of structures saturated with fluid.

5. During the use of method of reflected wave longitudinal reflected waves with lateral axis phase synchronism shortly extended from water-oil and water-gas contacts are registered.

6. On gravimetric fields (charts of gravity anomaly) hydrocarbon accumulations are highlightted by presence of local minimums [9-12].

7. In presence of fluids in geological cross-section high temperatures and pressures (AHRP and AHPoP) are observed.
8. Hydrocarbon deposits are found along well borehole according to the lateral logging sounding with definition of true resistivity and self polarization. In presence of hydrocarbon compounds resistivity is very high, while in the presence of formation water resistivity is low [13-15].

9. In contrast to true velocity and density in presence of hydrocarbons in geological structure true values of resistivity are very high, while in presence of saline and fresh reservoir water true resistivity values, as velocity and density values, are very low [16-17].

\section{Conclusion}

Use of geologic criteria and geophysical features allow discovering hydrocarbon accumulation and places of its high concentration in geological cross-section because they are determined based on processes of oil and gas formation and study of geological structure of territory of interest.

\section{References}

1. Guliev I.I. Sovremennye vzgliady na proiskhozhdenia nefti i qaza [Modern views on the origin of oil and gas]. Nauchnye trudy NIPI “Neftegaz”. Baku, 2013, no.4, pp.21-24.

2. Razin A.V., Merkulov V.P., Chernov S.A. Primenenie geofiziki pri izuchenii mestorozhdeniia nefti i qaza [Application of geophysics in the study of oil and gas fields]. Tsentr professional'noi perepodgotovki spetsialistov neftegazovogo dela TPU. Tomsk, 2004. 332 p.

3. Gurbanov V.Sh., Sultanov L.A. O neftegazonosnosti mezozoiskikh otlozhenii Azerbaidzhana [On oil-and-gas content of Mesozoic deposits in Azerbaijan]. Bulletin of PNRPU. Geology. Oil \& Gas Engineering \& Mining, 2015, no.16, pp.7-13.

4. Gurvich I.I., Boganik G.N. Seismicheskaia razvedka [Seismic exploration]. Moscow: Nedra, 1990. $551 \mathrm{p}$.

5. Gurvich I.I., Nomokonov V.P. (Ed.) Seismorazvedka [Seismic exploration]: spravochnik geofizika. Moscow: Nedra, 1981. 464 p.
6. Potapov O.A. (Ed.) Interpretatsiia dannykh seismorazvedki [Interpretation of the seismic data]: spravochnik. Moscow: Nedra, 1990. 448 p.

7. Boganik G.N., Gurvich I.I. Seismorazvedka [Seismic exploration]: uchebnik dlia vuzov. Tver': Izdatel'stvo AIS, 2006. 744 p.

8. Sultanov L.A., Nadzhaf-Kulieva V.M., Abbasova G.G. O zakonomernosti raspredeleniia skorosti prodol'nykh voln i plotnosti osadochnykh porod Prikaspiisko-Kubinskoi oblasti i mezhdurech'ia Kury i Gabyrry [About regularity of distribution of primary longitude waves rate and density of sedimentary rock in Pre-Caspian-Quba region and interfluve of Kura and Gabyrra]. XX Gubkinskie chteniia. Moskow, 2013.

9. Mudrecova E.A. (Ed.) Gravirazvedka [Gravity prospecting]: spravochnik geofizika. Moscow: Nedra, 1981. 397 p.

10. Mudrecova E.A., Veselov K.E. (Ed.) Gravirazvedka [Gravity prospecting]: spravochnik geofizika. Moscow: Nedra, 1990. 607 p. 
11. Khmelevskoi V.K., Gorbachev Iu.I., Kalinin A.V., Popov M.G., Seliverstov N.I., Shevin V.A. Geofizicheskie metody issledovaniia [Geophysical methods of investigation]: uchebnoe posobie dlia geologicheskikh spetsial'nostei vuzov. Petropavlovsk-Kamchatskii: Izdatel'stvo KGPU, 2004. 227.

12. Guliev I.I. Opredelenie glubiny anomaloobrazuiushchego ob"ekta proizvol'noi formy na osnove lokal'noi anomalii sily tiazhesti [Determination of depth of object that form anomalies of any form on basis of local gravity anomalies]. Geofizicheskie novosti Azerbaidzhana, 2014, no.1-2, pp.44-47.

13. Latyshova M.G., Martynov V.G., Sokolova T.F. Prakticheskoe rukovodstvo po interpretatsii dannykh GIS [Practical guidance for GIS data interpretation]: uchebnoe posobie dlia vuzov. Moscow: Nedra-Biznescentr, 2007, 327 p.
14. Guliev I.I. Interpretatsiia dannykh geofizicheskikh issledovanii skvazhin pri prognozirovanii uglevodorodnykh zalezhei [Interpretation of well survey data during hydrocarbon deposits prediction]. Azerbaidzhan geologu, 2013, no.17, pp.61-66.

15. Zaporozhec V.M. (Ed.) Geofizicheskie metody issledovaniia skvazhin [Well logging]: spravochnik geofizika. Moscow: Nedra, 1983. 591 p.

16. Dakhnov V.N. Elektricheskaia razvedka neftianykh i gazovykh mestorozhdenii [Electrical exploration of oil and gas fields]. 2 izdanie. Moscow-Leningrad: Gostoptekhizdat, 1953. 498 p.

17. Babazade O.B., Guliev I.I. Obnaruzhenie uglevodorodnykh zalezhei v estestvennykh usloviiakh zaleganiia metodami soprotivlenii [The discovery of hydrocarbon accumulations under natural conditions of occurrence by resistivity method]. Izvestiia vysshikh tekhniches-kikh uchebnykh zavedenii Azerbaidzhana, 2015, no.6, pp.18-24.

\section{Список литературы}

1. Гулиев И.И. Современные взгляды на происхождение нефти и газа // Научные труды НИПИ «Нефтегаз». - 2013. - № 4. - С. 21-24. DOI: 10.5510/OGP20130400173.

2. Разин А.В., Меркулов В.П., Чернов С.А. Применение геофизики при изучении месторождения нефти и газа / Центр профессиональной переподготовки специалистов нефтегазового дела ТПУ. - Томск, 2004. - 332 с.

3. Гурбанов В.Ш., Султанов Л.А. О нефтегазоносности мезозойских отложений Азербайджана // Вестник Пермского национального исследовательского политехнического университета. Геология. Нефтегазовое и горное дело. - 2015. № 16. - C. 7-13. DOI: 10.15593/2224-9923/2015.16.1.

4. Гурвич И.И., Боганик Г.Н. Сейсмическая разведка. - 3-е изд., перераб. - М.: Недра, 1980. - 551 c.

5. Сейсморазведка: справочник геофизика / под ред. И.И. Гурвич, В.П. Номоконова. - М.: Недра, 1981. - 464 с.

6. Интерпретация данных сейсморазведки: справочник / под ред. О.А. Потапова. - М.: Недра, 1990. - 448 с.
7. Боганик Г.Н., Гурвич И.И. Сейсморазведка: учеб. для вузов. - Тверь: Изд-во АИС, 2006. - $744 \mathrm{c}$.

8. Султанов Л.А., Наджаф-Кулиева В.М., Аббасова Г.Г. О закономерности распределения скорости продольных волн и плотности осадочных пород Прикаспийско-Кубинской области и междуречья Куры и Габырры // ХХ Губкинские чтения. - М., 2013.

9. Гравиразведка: справочник геофизика / под ред. Е.А. Мудрецовой. - М.: Недра, 1981. - 397 c.

10. Гравиразведка: справочник геофизика / под ред. Е.А. Мудрецовой, К.Е. Веселова. - М.: Недра, 1990. - 607 с.

11. Геофизические методы исследования: учеб. пособие для геологических специальностей вузов / В.К. Хмелевской, Ю.И. Горбачев, А.В. Калинин, М.Г. Попов, Н.И. Селиверстов, В.А. Шевнин. - Петропавловск-Камчатский: Изд-во КГПУ, 2004. - 227 с.

12. Гулиев И.И. Определение глубины аномалообразующего объекта произвольной формы на основе локальной аномалии силы тяже- 
сти // Геофизические новости Азербайджана. 2014. - № 1-2. - C. 44-47.

13. Латышова М.Г., Мартынов В.Г., Соколова Т.Ф. Практическое руководство по интерпретации данных ГИС: учеб. пособие для вузов. - М.: Недра-Бизнесцентр, 2007. - 327 с.

14. Гулиев И.И. Интерпретация данных геофизических исследований скважин при прогнозировании углеводородных залежей // Азербайджан геологу. - 2013. - № 17. C. 61-66.
15. Геофизические методы исследования скважин: справочник геофизика / под ред. B.M. Запорожца. - М.: Недра, 1983. - 591 с.

16. Дахнов В.Н. Электрическая разведка нефтяных и газовых месторождений. - 2-е изд. М.-Л.: Гостоптехиздат, 1953. - 498 с.

17. Бабазаде О.Б., Гулиев И.И. Обнаружение углеводородных залежей в естественных условиях залегания методами сопротивлений // Известия высших технических учебных заведений Азербайджана. - 2015. - № 6. - С. 18-24.

Please cite this article in English as:

Gurbanov V.Sh., Babazade O.B., Sultanov L.A., Guliev I.I. Discovery of hydrocarbon accumulations formed under natural conditions of occurrence based on field data. Bulletin of PNRPU. Geology. Oil \& Gas Engineering \& Mining, 2016, vol.15, no.19, pp.114-121. DOI: $10.15593 / 2224-9923 / 2016.19 .2$

Просьба ссылаться на эту статью в русскоязычных источниках следующим образом:

Определение наличия углеводородных залежей в естественных условиях залегания на основе практических данных / В.Ш. Гурбанов, О.Б. Бабазаде, Л.А. Султанов, И.И. Гулиев // Вестник Пермского национального исследовательского политехнического университета. Геология. Нефтегазовое и горное дело. - 2016. - Т. 15, № 19. - С. $114-121$. DOI: $10.15593 / 2224-9923 / 2016.19 .2$ 